deficiency mutation has occurred in this and at least in another, namely, the East-Baltic race, at some time or other. It is probable that the mutations for skin, hair and eye colours have taken place separately. In the Baltic tribes, the high rate of the deficiency mutation might probably account for the larger percentage of the blond as compared to the Hindukush tribes, among whom the activators are perhaps dominant over suppression, causing the general persistence of the more pigmented people.

Lastly, an intruding Mongoloid element must also be responsible for the yellowish tint in the skin colour and broad flat nose found among many individuals.

The proportions of these strains vary in different parts. The Dinaric and the Proto-Nordic elements are stronger in the western valleys, whereas the basic Oriental and the Mongoloid elements are more conspicuous in the eastern valleys of the Upper Indus.

\section{Breeding Investigations in the Sugar-Cane}

Hybridization in and with the genus Saccharum formed the topic of Rao Bahadur T. S. Venkatraman's presidential address to the Section of Agriculture. Hybridization in the sugar-cane at the Imperial Sugar-cane Station at Coimbatore represents the first attempt to improve the subtropical types of canes. This genetical work, which has been going on at the Station for more than twenty-five years, has involved six species of Saccharum and four genera. There appear to be two distinct groups of wild species of Saccharum, both of which are confined to south-east Asia. Some of the wild species show wide variations. For example, a survey of the Indian wild species, $S$. spontaneum, showed a variation in sugar content of the juice from 0.5 per cent to 17.0 per cent, the latter figure being higher than that of certain cultivated Indian canes.

The Indian canes belonging to the species $S$. barberi are cultivated in subtropical India, though some are found farther south. Certain Indian canes cannot be ascribed to the genus Saccharum, the most important being the Mungo group of Dr. Barber.

A wide range of forms is known to arise from sugar-cane seed. This is explained by the heterozygous nature of the parents and the fact that most sugar- canes in cultivation are polyploid; for example, S. offinarum is octoploid.

Very little in-breeding has taken place in the sugarcane, but much work has been done on inter-varietal, inter-specific and even inter-generic hybridization. Inter-varietal hybridization has been confined mostly to $S$. officinarum. At Coimbatore, economically important inter-specific hybrids have been obtained from S. officinarum $\times S$. spontaneum. In Australia and Hawaii, $S$. robustum is being used for producing hardier seedlings for tropical regions.

At Coimbatore, inter-generic hybridization has been carried out, using such genera as Sorghum and Bambusa. The Sorghum cross was introduced to produce a shorter life-cycle which in the sugar-cane is from twelve to even twenty-four months. Hybrids producing a crop in seven months have been produced, and these have had high quality juices. Growth vigour in these, however, has proved disappointing. Crossing with the bamboo (Bambusa) has been introduced in order to obtain greater vigour, but experimental work has not proceeded far enough yet to justify definite conclusions, from the economio point of view.

The previously mentioned inter-generic hybrids have shown some interesting phenomena with regard to the manner in which the characters are shown in the $F_{1}$ generation and transmitted in further back. crosses with either parent. In both the Sorghum and Bambusa hybrids with sugar-cane, the one fact that stands out prominently is the general dominance of Saccharum characters in the $F_{1}$ generation.

In the case of Saccharum $\times$ Sorghum hybrids, the general dominance of Saccharum characters was found to persist even after twice back-crossing the hybrids with their Sorghum parent. Certain of the Sorghum hybrids exhibited morphological characters not found in either parent. Most of these hybrids were infertile in their first generation. On further vegetative propagation, however, some of them are showing an increasing fertility in the sexual organs with the result that, whereas in the earlier years no seeds could be obtained from these, it has since been possible to raise seedlings in large numbers from some of them and also to back-cross them with the two parents.

[To be continued.]

\title{
The Prehistoric People of Palestine*
}

\section{By Sir Arthur Keith, F.R.S.}

\begin{abstract}
$\mathrm{T}$ HE fossil remains of the earliest inhabitants of Palestine were discovered in caves of Mount Carmel by an expedition led by Miss Dorothy Garrod, and financed by two societies - the British School of Archæology in Jerusalem and the American School of Prehistoric Research. The early Palestinians were quite unlike any people now living, but are of profound interest, because, if not our actual ancestors, they are certainly near akin to the human stock which in the course of time gave the world its Caucasian or white inhabitants. Hitherto our search for the fossil ancestor of the white man has been in

* Substance of a lecture given by Sir Arthur Keith at the Royal College of Surgeons on February 14.
\end{abstract}

vain. Everyone is familiar with the place held by Palestine in our conception of human life at the dawn of history; the excavations made at Mount Carmel by Miss Garrod are destined to give that small country in the East an equally important place in our picture of man's prehistoric world.

What the expedition found was this. Man began to inhabit the caves of Mount Carmel long before the onset of the last glaciation of Europe. One cave from an archæologist's point of view is the richest ever opened; it was filled with fossiliferous earth tramped down by the feet of prehistoric man, until an accumulation more than 80 feet in depth had been formed. From bottom to top the strata were 
pregnant with man's stone tools, with the fossil bones of animals-many of them of extinct species, and with the bones of the men and women who fashioned and used the tools. It is no exaggeration to say that these deposits record the history of man in Palestine for a period of at least 100,000 years; the period may be longer; the future is not likely to prove that it was shorter. The strata begin while man is still in an early stage of stone culture; they leave off about the time of Abraham. There is no need to tell how each stratum has been made a page of history; the story is told by Miss Dorothy Garrod and Miss Dorothea Bate in a volume just issued by the Oxford University Press [see p. 304 of this issue].

Hitherto we have had to build our knowledge of prehistoric man out of fossil scraps. At Mount Carmel complete skeletons were found; one small cave, excavated by Mr. T. D. McCown of the American School, proved to be a veritable cemetery; fossil remains of ten individuals were found in it-three of them complete skeletons-the others were disturbed burials. Altogether we know thirteen of the fossil Carmelites by name or number. We have become familiar with all of them. Four are children, all the adults are less than fifty years of age, save one. Only one had turned fifty at the time of death. The expectation of life was not good among these early inhabitants of Palestine.

We owe so complete a representation of this prehistoric community to certain circumstances: (1) the careful way in which the dead had been buried; (2) to the fact that Mount Carmel is composed of limestone, and limestone tends to the preservation of bones better than any other rock. If the limestone helped to preserve the Carmelite bones, it also made their extraction a matter of extreme difficulty. $\mathrm{Mr}$. McCown, realizing the impossibility of removing the bones piecemeal in the cave, cut out the bone-con. taining breccia-hard as cement-in blocks weighing a ton or more, and had them conveyed from the slopes of Mount Carmel to the Museum of the Royal College of Surgeons in Lincoln's Inn Fields, London. The rougher work of extraction was done at the Museum but the finer work, including restoration, examination, comparison, drawing and photography of the various bones were done, by permission of the President and Council of the College of Surgeons, at the Buckston Browne Research Farm, Downe, where, within sight of Darwin's old home, Mr. McCown and I restored the old Palestinians to life-or as near to their living state as is now possible. Mr. McCown and I began our task in the autumn of 1933 ; the final account of what we had done and seen was drawn up for publication at the end of 1937. Thanks to Dr. J. Beattie, conservator of the Museum of the Royal College of Surgeons, our task was made easy.

What kind of people were those early dwellers on Mount Carmel ? The Bible records in the book of Genosis that before the flood "there were giants in the land". The fossil people we are now dealing with are almost worthy of such a name. The men were tall; four of them range in height from $5 \mathrm{ft}$. 8 in. to $5 \mathrm{ft} .11 \mathrm{in.}$ The women, on the other hand, were of short stature, varying from $5 \mathrm{ft}$. to $5 \mathrm{ft} .4 \mathrm{in}$. We have been able to study every bone of the fest, hands and limbs of this ancient people; they had straight and strong limbs, walking and running as we do, and yet every bone differs in detail from our bones. Their chests were ample; we infer they were runners and long-winded. We have studied their spinal columns; their vertebræ still retain certain simian details in their conformation. It is so with the bones of their hands and arms; in certain points they are peculiar. We have been able to measure their heads and in some cases to take casts of their skull cavities and thus obtain a crude picture of the conformation of their brains. Although the fossil men of Mount Carmel are separated from us in time by the space of a whole glacial epoch, yet in point of size they had already brains which were equal to ours, although as regards convolutionary pattern, theirs were the simpler. The muscles of their tongues were attached to their lower jaws as ours are; all the parts of the brain which indicate a capacity for speech were present.

In their anatomy they still retained many primitive marks. Their eyebrow ridges, like those of the gorilla, form great bars of bone above the orbits; their jaws are massive; their mouth cavities were very much more capacious than ours. Their necks were thick and exceedingly strong.

Nowhere in the world of to-day could there be found a local group of people showing the wide range of structural variation of our fossil Palestinians. Chins were at every stage of evolution-from a chinless stage comparable to that of the chimpanzee, to chins of moderate development. One of the most distinctive of human features is the nose; in noseform, the Palestinians were not uniform ; in one the size of the bridge and general prominence might well be the prototype of the Roman nose ; in another, an opposite condition-almost negroid-prevailed. We found it possible to arrange the individuals of the group in a series; at one end, a woman had her closest affinities to the very primitive Neanderthal type of Europe; at the other end of the series, a man known to us as Skhūl IV might be a crude form of an early European. We seem to be dealing at Mount Carmel with a plastic folk in the throes of evolutionary change.

To fit the fossil Palestinians into their place in our picture of ancient humanity we have to think geographically. We now know that before the last glacial epoch set in, Europe was inhabited solely by peoples of the Neanderthal type; their fossil remains have been found as far west as the Island of Jersey and as far East as the Crimea. As we go eastwards, the type approximates somewhat to that which we have now found in Palestine. In Mount Carmel we have a people whose date is earlier, not later than that of the Neanderthalians of Europe. Our Mount Carmel people have many points of resemblance to the Neanderthalians of Europe, and yet in many they differ. In those points wherein the Palestinians differ from the Neanderthalians, they are Caucasian or modern.

Have we, then, reached the homeland of Europeans in Palestine-the Eden in which Neanderthal man evolved into man of the modern type ? That is not the inference Mr. McCown and I are inclined to draw ; we believe that, as research is carried further into Western Asia, we shall find the fossil remains of men who have still less of the Neanderthalians in them and more of us moderns than is the case at Mount Carmel.

The first glimpse we have in Europe of the early Caucasians or 'whites' is obtained when the crisis of the last glaciation was passing. They then appear in South Europe as Cromagnons and in central Europe as Predmostians. Hitherto we did not know whence these early representatives of our type had come. The discovery at Mount Carmel suggests that 
we shall find their homeland in Western Asia. Our tall men of Mount Carmel have many structural points in common with the tall Cromagnon. History, it is said, repeats itself ; the Cromagnons blazed the trail from Asia to Europe; the ancient Palestinians may not be the ancestors of the Cromagnons but only distant relatives; at a much later date, Western Asia gave Europe its forms of speech and also, we presume, the primitive speakers of the Aryan tongue.

The most surprising result of the excavation of the caves of Mount Carmel is the light thrown on the mentality of early stone-age mankind. Care of the dead is one of the hall-marks of humanity. The Mount Carmel people had a care for their dead. The youngest child was placed in its grave in a sitting position with limbs flexed under the trunk and arms folded. The tallest of the men had in his embrace the fossil jaw of a boar ; we do not suppose it was in a fossil state when placed in his dead arms; we suppose it carried with it a meal of which he had been fond-a pig's tongue. We must also suppose that those who placed the supply of food in the grave beside him believed that death was not the end of life. Even thus early man seems to have softened the blow of death with a hope of immortality.

Another very unexpected discovery was this. When the hip joint of one of the men was cleared of limestone breccia, it was found to be shivered. On closer examination a perforation was found at the centre of the injury, filled in with cave earth. When the earth was removed from the perforation of femur and pelvis and a cast taken of it, we had before us the image of a four-side spear-head. We did not know that such weapons had been invented at so early a date; we believed that the only fighting weapons possessed by men then were stone clubs. A spear to penetrate the whole thickness of the hip joint of a large-framed man and to enter the pelvis as this weapon did must have been finely tempered and driven with exceeding force.

\section{Science News a Century Ago \\ Solidification of Carbonic Acid}

QUoTINe from the Scotsman, the Mechanics' Magazine of February 24, 1838, said : "Mr. Kemp, of Edinburgh, who has been so successful in his experiments upon the liquefaction of the gases, has succeeded in reducing carbonic acid gas to the solid state. This experiment, which had been previously shown in Dr. Hope's class-room, Mr. Kemp exhibited before the Wernerian Society at their last meeting, in the presence of Professors Jameson, Forbes, Graham, Trail, Welsh, Pillans, Dr. Neill, and a number of other scientific gentlemen. The gas requires a pressure of thirty-six atmospheres to reduce it to the liquid form. When the pressure was removed by opening a small stopcock on the con. densing apparatus, the cold, produced by the rapid evaporation of the liquid, was so great, that the whole mass was almost instantly reduced to the solid state; and in this condition, although the tem. perature could not have been less than 180 degrees below zero Fahrenheit, it was handled and tasted by many of the gentlemen present. . . . This is the first time that the solidification of carbonic acid has been accomplished in Great Britain. Many important results may be expected to accrue from it . . . there can be no doubt, that any liquid may be frozen by it, and it will be a powerful agent in producing the condensation of those gases which have hitherto resisted all attempts to reduce them to their liquid form."

Kenneth Kemp, who for some years assisted the professor of chemistry, Thomas Charles Hope (17661844), died in 1843 at the early age of thirty-six years.

\section{Reform of the Patent Law}

IN the issue of The Railway Magazine and Annals of Science of February 1838, is a contribution by Mr. J. Hacket entitled "Suggestions on a New System of Granting Patents for Inventions". After a brief review of the Patent Law at that time and the disabilities inventors suffered from and the loss to society through the discouraging effects of the system which then prevailed, the writer went on to say that nothing short of a new system based upon a new principle was required. "The only measure that I can conceive," he said, "calculated to produce the beneficial effects so much required, is a national institution, in which are a number of suitable apart. ments, with models, plans and specifications of the most useful machines, manufactures, etc., now in use, patented and unpatented, classed in proper orderover each department in the proposed national establishment, persons suitably qualified should be appointed to arrange in order, protect from injury, and be accountable for every model, plan and specification committed to their charge." Individuals desirous of obtaining a patent were to send notice to the secretary of the institution and, on the receipt of the plans and specifications and a fee of $£ 1$, protection was to be obtained for one year. At the expiration of this year, or the patent being put into operation, $£ 5$ annually was to be paid.

\section{Wind Measurements at Birmingham}

IN a letter published in the Athenceum of February $24,1838, \mathrm{Mr}$. William Ick, the curator of the Birming. ham Philosophical Institution, gave some observations made with a self-recording anemometer and a rain gauge. In a violent gale on December 18, 1837, he said, which continued without intermission for 14 hours, the anemometer registered the highest force of the wind as $16 \frac{1}{2}$ pounds on the square foot. This gale was exceeded on December 20 when the highest pressure recorded was 214 pounds. Other records were taken on January 2 and February 9,12 and 15 of 1838. "I shall offer no comments on these facts," he added. "The British Association have voted a sum for the erection of an anemometer at Plymouth, and Mr. Osler has very nearly completed the instru. ment. If another were erected in the northern part of the island, and several others in distant stations judiciously chosen, in the continents of Europe and America, a comparison of the results might in a few years furnish important information respecting the laws which regulate the force and direction of aerial currents and their influence on temperature, humidity, etc."

The inventor of the anemometer to which $\mathrm{Mr}$. Ick referred was Abraham Follet Osler, who was born in Birmingham on March 22, 1808, and succeeded to the glass-making business of his father, which he carried on until 1876. His self-registering meteorological instruments were installed at Greenwich and elsewhere. He was elected fellow of the Royal Society in 1855 and died at Edgbaston on April 26, 1903. 